\title{
Semiotic analysis of Royco's flavoring advertisements on television
}

\author{
Ajeng Dinar Wisesa Wardhani*), \\ Universitas Indraprasta PGRI \\ *) Correspondences author: Perumahan Bogor Nirwana Residence, Cluster Harmony 2, Blok H2-1 No. 70, Taman Sari, Bogor, \\ Indonesia; \\ e-mail: ajengdinar13@gmail.com
}

\begin{abstract}
An advertisement constitutes one of the important efforts for producers to open any relation to their consumers. It is known as one of the great way increasingly their trading. All of those things, by using advertisements those commercial goods can be known and be sold.Television is one of their choices to market their product. This research is talking about advertisement, by using Roland Barthes Semiotic theories, combining Seassurian Structuralism theory. Actually, Seassure theory consider as the basic of Barthes' theories. Basically, Semiotic is a theory to show how is meaning created and communicated in messages that are primarily visual. Semiotic approach analyse the sign, icon, and symbol in television advertisements to intrepreting its meaning. The production of meaning from visual messages, like advertisment has not been clearly investigated to designers of advertising messages. The difficulty of taking visual meaning is the main reason of structured research approaches to code and categorize such information.
\end{abstract}

Key Words: Research; advertisement; semiotic; and meaning.

Article History: Received: 10/06/2018; Revised: 09/07/2018; Accepted: 11/08/2018; Published: 22/08/2018

How to Cite (MLA $7^{\text {th }}$ ): Wardhani, Ajeng Dinar Wisesa "Semiotic analysis of Royco's flavoring advertisements on television" Hortatori Jurnal Pendidikan Bahasa dan Sastra Indonesia 2.1 (2018): 01-08. Print/Online. Copyrights Holder: Wardhani, Ajeng Dinar Wisesa. First Publication: Hortatori Jurnal Pendidikan Bahasa dan Sastra Indonesia (2018).

This work is licensed under a Creative Commons Attribution-ShareAlike 4.0 International License.

\section{Pendahuluan}

Mempelajari ilmu bahasa bukan hanya diinterpretasikan sebagai sebuah ilmu dalam mempelajari struktur dalam bahasa tersebut, tidak terkecuali bahasa Indonesia. Akan tetapi, hal ini termasuk bagaimana kita menganalisis suatu wacana yang ada di dalam masyarakat. Teks yang dapat dibaca tidak hanya sebuah teks yang tertulis dalam sebuah buku, majalah, novel atau pun surat kabar. Sebuah gambar ataupun sebuah percakapan dapat digolongkan dalam sebuah teks. Ilmu yang mempelajari hal ini dinamakan semiotika. Semiotika merupakan sebuah ilmu yang mempelajari dan menemukan makna di balik sebuah tanda dalam komunikasi. Kata semiotika berasal dari bahasaYunani, semeion yang berarti tanda. Tanda dapat diartikan sebagai segala sesuatu yang dapat memiliki makna mewakili hal lain bukan tanda itu sendiri.

Salah satu media komunikasi massa yang berkembang dan berperan besar dalam penyebaran informasi dan hiburan ke semua lapisan masyarakat adalah televisi. Dana yang besar sangat mempengaruhi perkembangan media komunikasi ini. Sumber terbesar guna mendapatkan dana tersebut berasal dari tayangan iklan di televisi. Televisi sebagai salah satu media yang banyak dimiliki oleh masyarakat, memiliki keunggulan dalam bentuk informasi audiovisual yang menarik. Bentuk informasi audio visual yang disuguhkan oleh televisi sangat berperan dalam mengiklankan suatu produk. Informasi mengenai barang atau jasa akan dapat dengan mudah diketahui secara langsung melalui iklan yang ditayangkan di televisi. Hal ini senada dengan pendapat Kusumawati, 2010 (https://eprints.uns.ac.id/278/1/169981511201010311.pdf, diunduh 23 Desember 2016). Dapat dikatakan bahwa iklan merupakan salah satu cara penyampaian informasi sehingga membuat orang yang menjadi 
target menerima pesan dari iklan tersebut, baik itu sekedar informasi atau dalam kaitan membangun citra positif sehingga orang tersebut tertarik.

Pembuat iklan haruslah pintar dan cermat dalam memilih kata-kata yang akan mereka gunakan dalam sebuah iklan, sehingga iklan yang dihasilkan merupakan iklan yang tepat sasaran dan mempengaruhi orang yang menontonnya. Kesuksesan tayangan iklan dipengaruhi oleh pemilihan kata yang mengandung gaya bahasa dan makna gaya bahasa yang tepat. Pengungkapan pikiran secara khas melalui bahasa, dapat dilakukan dengan penggunaan gaya bahasa. Keraf (2010:113) mengatatakan bahwa penggunaan gaya bahasa akan menghindari sikap monoton dalam berbahasa, begitu pula penggunaan bahasa dalam iklan.

Pada analisis semiotik, seorang peneliti berusaha menemukan makna tanda dan hal-hal tersembunyi dibalik sebuah tanda dalam teks, iklan, bahkan berita karena sistem tanda bersifat kontekstual dan bergantung pada penggunanya. Dalam konteks penelitian iklan televisi, mengaitkan semiotika dan iklan dapat menjadi suatu analisis yang menarik. Sebagian iklan yang ditayangkan bukan hanya hendak menawarkan suatu produk semata, namun berupaya melekatkan nilai dan sistem keyakinan tertentu termasuk budaya. Dalam catatan Graeme Burton (2007: 40), barang-barang yang diiklankan di televisi akan memperoleh nilai kultural. Iklan yang pada dasarnya ditujukan untuk kegiatan promosi atas suatu produk menjadi kegiatan pemasaran seperangkat nilai dan produksi suatu keyakinan.

Dalam lingkungan kebudayaan modern, iklan dan televisi merupakan hubungan simbiosis mutualistis yang tidak dapat dipisahkan. Produsen memerlukan televisi untuk mempromosikan produknya, sedangkan stasiun televisi membutuhkan dana untuk menjalankan kegiatannya demi menjaga eksistensinya. Bertemunya masing-masing kebutuhan tersebut membuat suatu tayangan iklan menjadi lumrah muncul di televisi. Dalam lingkup komunikasi massa, kehadiran iklan televisi tidak hanya merupakan bentuk propaganda yang bersifat menghibur dan menyenangkan tetapi juga memberikan informasi.

Salah satu fenomena yang menarik yang terjadi di negara kita saat ini adalah era persaingan ketat antar produk-produk yang ditawarkan kepada masyarakat, seperti produk makanan, rumah tangga, elektronik dan lain sebagainya. Dengan melihat ini semua dapat dikatakan bahwa Indonesia adalah tempat strategis bagi bagi persaingan dan perkembangan segala produk. Hal ini juga didukung oleh sifat konsumtif bangsa kita. Melalui sumber informasi seperti televisi, radio, majalah, koran, bahkan dari sebuah situs internet, masyarakat bisa mendapatkan informasi tentang berbagai produk, termasuk harga yang ditawarkan. Melihat fenomena tersebut, para produsen tentu berpikir keras agar produk yang mereka tawarkan laku keras di pasaran. Salah satu cara agar produk mereka dapat unggul di pasaran adalah dengan membuat iklan semenarik mungkin. Adapun pengertian iklan menurut Widyatama (2005) adalah bentuk penyajian pesan yang dilakukan oleh komunikator secara personal melalui media dan ditujukan kepada komunikan dengan cara membayar.

Periklanan merupakan suatu cara jitu dalam usaha produsen dalam membuka hubungan dengan dunia luar, yaitu pemasaran produk kepada konsumen. Periklanan merupakan salah satu cara memajukan usaha yang dilakukan produsen karena melalui iklanlah barang ataupun jasa yang dihasilkan diperkenalkan dan dipasarkan kepada konsumen. Televisi dan media cetak merupakan salah satu pilihan bagi produsen dalam memasarkan produknya. Televisi mempunyai kemampuan yang lebih unggul dalam mendemonstrasikan penggunaan suatu produk dibandingkan media cetak karena mampu dijangkau melalui indera pendengaran dan penglihatan secara bersamaan oleh konsumen. Selain itu, televisi mempunyai kemampuan untuk memunculkan iklan yang berlainan tanpa diharapkan yang tidak dapat dilakukan oleh media lainnya. Iklan televisi menarik seseorang untuk menggunakan inderanya, baik pada saat orang tersebut ingin menonton iklan atau pun tidak.

Periklanan adalah proses komunikasi massa yang melibatkan pihak produsen tertentu, yakni sang pengiklan, yang membayar kepada media massa untuk sebuah jasa atas penyiaran iklannya, baik melalui media cetak seperti surat kabar, majalah, spanduk, dan lain-lain atau media elektronik seperti televisi, radio, dan internet). Periklanan Menurut kamus istilah periklanan Indonesia adalah pesan yang dibayar dan disampaikan melalu sarana media, antara lain pers, radio, televisi, bioskop, yang bertujuan membujuk konsumen untuk melakukan tindak membeli atau mengubah perilakunya (Nuradi, 1996:4).

Kehadiran semiotik saat ini memberi kita ruang untuk memaknai pesan dari sebuah tanda. Dalam kehidupan sehari-hari banyak hal dikomunikasikan melalui tanda-tanda, maka tidak salah kiranya jika tanda adalah dasar dari komunikasi. Dengan semiotik banyak tanda bisa kita ketahui maknanya, tidak hanya tanda 
dalam adegan film atau sinetron, atau kata-kata yang diucapkan oleh manusia, tapi tanda-tanda yang tercetak juga dapat kita ketahui maknanya melalui analisis yang ditawarkan oleh bidang ilmu ini. Menghubungkan teori ini dengan iklan, pesan yang dibawa dalam sebuah iklan tidak terlepas dari dua komponen yaitu teks dan visual yang saling mengisi antara satu dengan lainnya dan pada akhirnya memiliki arti tersendiri bagi para penerima pesan tersebut. Teks dan visual yang terlibat dalam pesan iklan dapat dikategorikan sebagai saluran komunikasi (channel) non personal yakni proses penyampaian pesan yang tidak mendapatkan respon dan umpan balik secara langsung dari para penerima pesan yaitu para penonton iklan.

Peneliti tidak akan membahas seberapa besar pengaruh pesan sebuah iklan terhadap konsumen yang menonton iklan tersebut di dalam penelitian ini. Peneliti akan mencoba memahami bagaimana benak pikiran penonton dipengaruhi oleh pesan melalui semiotika. Semiotika merupakan sebuah teori pemikiran yang awalnya berkembang di Eropa dan Amerika. Secara etimologis istilah semiotika berasal dari bahasa Yunani "semeion" yang berarti 'tanda' atau " seme" yang berarti "penafsir tanda". Semiotika merupakan sebuah studi tentang tanda/makna dan cara tanda-tanda/makna-makna itu bekerja (Sobur, 2004:12). Tanda yang memiliki makna dalam sebuah pesan iklan yang hadir dalam bentuk visual akan memberikan dan membangun sebuah pemahaman tersendiri jika dibandingkan dengan bentuk teks bagi para pembacanya.

Menelaah hal ini, ahli filsafat dan tokoh terkemuka dalam semiotika modern, Amerika Charles Sanders Peirce (Zoest, 1992), menegaskan bahwa manusia hanya dapat berfikir dengan sarana tanda, manusia hanya dapat berkomunikasi dengan sarana tanda. Tanda yang dapat dimanfaatkan dalam senirupa berupa tanda visual yang bersifat non-verbal, terdiri dari unsur dasar rupa seperti garis, warna, bentuk, tekstur, komposisi dan sebagainya. Tanda-tanda yang bersifat verbal adalah obyek-obyek yang dilukiskan, seperti obyek manusia, binatang, alam, imajinasi atau hal-hal lain yang bersifat abstrak lainnya (Priyatno, 1998).

Dalam penelitian ini, peneliti tertarik untuk menliti iklan penyedap rasa bermerk Royco. Pada dasarnya setiap produk yang ditampilkan dalam sebuah iklan bertujuan untuk menarik konsumen agar menggunakan produk yang ditawarkan dari iklan tersebut. Setiap iklan pasti mempunyai makna yang tersembunyi. Lewat hubungan antara tanda (Sign), penanda (Signifier), dan petanda (Signified) kita akan diarahkan ke arah makna yang tersembunyi dari iklan tersebut.

Dalam menelaah pernyataan di atas, maka peneliti mengangkat masalah yang akan diteliti dalam penelitian ini yaitu: 1. Bagaimana tingkatan dan relasi tanda yang terdapat dalam iklan televisi Royco versi maemasak sop?. 2. Bagaimana pesan iklan terbentuk berdasarkan elemen visual iklan televisi Royco versi sop?

Adapun pembatasan masalah yang akan diteliti adalah pembatasan masalah memfokuskan penelitian pada objek iklan televisi Royco versi memasak sop. Iklan televisi Royco versi memasak sop menarik untuk diteliti karena dalam iklan ini terdapat elemen-elemen visual yang cenderung digunakan pada iklan-iklan yang ditujukan untuk anak-anak, meskipun produk Royco dilihat dan dipahami oleh khalayak atau calon pembeli.

\section{Kajian Pustaka}

Dewasa ini, iklan begitu berkembang pesat dan marak bermunculan dalam media cetak, elektronik, media online maupun media luar ruang. Jenis iklan pun beragam, bisa berupa iklan produk komersial maupun layanan masyarakat. Pesan komunikasi pada sebuah iklan mudah dipahami dan diingat oleh orang yang melihat, mendengar, dan membacanya. Kreativitas pada sebuah iklan telah menjadi unsur penting dalam kehidupan sosial. Selain sebagai alat untuk memasarkan suatu produk, jasa, dan informasi publik, iklan juga telah mengenalkan nilai-nilai yang mempengaruhi gaya hidup masyarakat.

Iklan sebagai sebuah teks merupakan sistem tanda terorganisir menurut kode - kode yang merefleksikan nilai - nilai, sikap dan juga keyakinan tertentu. Setiap pesan dalam iklan memiliki dua tingkatan makna yaitu makna yang dinyatakan secara eksplisit di permukaan iklan dan makna yang dinyatakan secara implisit di balik permukaan iklan. Dengan demikian, untuk mengetahui kontruksi makna yang terjadi dalam iklan dengan menekankan peran sistem tanda dengan konstruksi realitas digunakan metode semiotika sehingga ideologi - ideologi di balik iklan bisa dikupas. Semiotika adalah suatu bentuk 
strukturalisme, karena ia berpandangan bahwa manusia tidak bisa mengetahui dunia melalui istilahistilahnya sendiri, melainkan hanya melalui struktur-struktur konseptual dan linguistik dalam kebudayaan.

Bagi para strukturalis, tugas ilmuwan adalah menyingkap struktur konseptual yang berdasarkan struktur tersebut berbagai kebudayaan mengorganisasikan persepsi dan pemahamannya atas dunia. Upaya strukturalisme adalah menemukan cara manusia memahami dunia, bukan seperti apakah dunia itu. Semiotika sebagai salah satu kajian media massa telah menjadi pendekatan penting dalam teori media sejak akhir tahun 1960-an, sebagai hasil pengembangan Roland Barthes.

Menurut Roland Barthes, semiotika adalah suatu ilmu atau metode analisis untuk mengkaji tanda. Tanda-tanda adalah seperangkat yang dipakai dalam rangka upaya berusaha mencapai jalan di dunia ini, di tengah-tengah manusia dan bersama-sama manusia. Ia pun membedakan dua pengertian (signification) dari semiotika yaitu denotasi dan konotasi. Denotasi adalah level deskriptif dan harafiah makna yang disepakati seluruh anggota budaya. Pada level konotasi, makna dihasilkan oleh hubungan antara signifier dan budaya secara luas yang mencakup kepercayaan-kepercayaan, tingkah laku, kerangka kerja dan ideologi dari sebuah formasi sosial. Semiologi, atau dalam istilah Barthes, semiologi, pada dasarnya hendak mempelajari bagaimana kemanusiaan (humanity) memakai hal-hal (things), memaknai (to signify) dalam hal ini tidak dapat dicampur adukkan dengan mengkomunikasikan (to communicate). Memaknai berarti bahwa objekobjek itu hendak berkomunikasi, tetapi juga mengkonstitusi sistem terstruktur dari tanda. (Sobur, 2003:15).

Semiologi menurut Saussure didasarkan pada anggapan bahwa selama perbuatan dan tingkah laku manusia membawa makna atau selama berfungsi sebagai tanda, harus ada di belakangnya sistem perbedaan dan konvensi yang memungkinkan makna itu. Di mana ada tanda di sana ada sistem (Hidayat, 1998:26). Sedangkan Peirce menamakan ilmu yang dibangunnya dengan nama semiotika (semiotics). Bagi Peirce yang ahli logika, penalaran manusia senantiasa dilakukan lewat tanda. Artinya, melalui tandalah manusia melakukan penalaran. Dalam pikirannya, logika sama dengan semiotika dan semiotika dapat ditetapkan pada segala macam tanda (Berger, 2000:11-22). Istilah semiotika selanjutnya lebih populer daripada semiologi.

Dalam menganalisis struktur bahasa dalam ilmu komunikasi massa, semua bentuk dan isi media massa pada dasarnya adalah tanda. Berita merupakan tanda, film merupakan tanda, gambar merupakan tanda, pembawa acara adalah tanda, bahkan media massa itu sendiri juga merupakan tanda. Menurut John Fiske (dalam Van Zoest, dalam Okke Zaimar dan Ida Husein, 1991), semiologi memiliki tiga bidang studi utama. Pertama, tanda itu sendiri. Hal ini terdiri atas studi tentang berbagai tanda yang berbeda, cara tandatanda yang berbeda itu dalam menyampaikan makna, dan cara tanda-tanda itu terkait dengan manusia yang menggunakannya. Tanda adalah konstruksi manusia dan hanya bisa dipahami dalam artian manusia yang menggunakannya. Kedua, kode atau sistem yang mengorganisasikan tanda. Studi ini mencakup cara berbagai kode dikembangkan guna memenuhi kebutuhan suatu masyarakat atau budaya atau untuk mengeksploitasi saluran komunikasi untuk mentransmisikannya. Ketiga, kebudayaan atau tempat kode tanda bekerja. Ini gilirannya tergantung pada penggunaan kode-kode dan tanda-tanda itu untuk keberadaan dan bentuknya sendiri.

Barthes mengembangkan penanda (signifier) dan petanda (signified) menjadi ekspresi (E) untuk penanda (signifier) dan isi (C/contenu) untuk petanda (signified). Namun, Barthes mengatakan bahwa antara $\mathrm{E}$ dan $\mathrm{C}$ harus ada relasi (R) sehingga membentuk tanda (Sn). Ia mengemukakan konsep tersebut dengan E-R-C. Konsep relasi ini membuat teori tentang tanda lebih mungkin berkembang karena $\mathrm{R}$ ditentukan oleh pemakai tanda (Hoed, 2011:45).

Setiap tanda selalu memperoleh pemaknaan awal yang dikenal secara umum (denotasi) dan oleh Barthes disebut sistem primer, sedangkan segi pengembangannya disebut sistem sekunder. Sistem sekunder yang ke arah ekspresinya disebut metabahasa, artinya $\mathrm{E}$ dapat berkembang membentuk tanda baru, sehingga ada lebih dari satu E untuk C yang sama. Dengan kata lain, suatu tanda mempunyai bentuk yang banyak dengan makna yang sama. Sedangkan sistem sekunder yang ke arah $\mathrm{C}$ disebut konotasi, artinya $\mathrm{C}$ dapat berkembang membentuk tanda baru, sehingga ada lebih dari satu $C$ untuk E yang sama(Hoed, 2011 : 45). Dengan kata lain suatu tanda mempunyai banyak makna dengan bentuk yang sama. 


\section{Metode}

Pada bagian metode, anda perlu menjelaskan bagaimana penelitian dilakukan. Hal ini bertujuan untuk (1) memungkinkan pembaca mengevaluasi penelitian anda, dan (2) memberikan petunjuk bagi pembaca untuk dapat mengulangi kajian penelitian yang telah anda lakukan di masa yang akan datang. Anda harus menjelaskan dengan tepat metode penelitian anda, seperti: apa metodenya, berapa banyak populasi dan sampelnya atau subjeknya, di mana tempat penelitiannya, kapan penelitian itu dilakukan (berapa lama), dan peralatan dan bahan penunjang yang digunakan dalam penelitian. Hal ini dibutuhkan untuk memastikan bahwa tersedianya informasi yang detail bagi pembaca untuk memverifikasi temuan penelitian anda dan membuka ruang bagi adanya studi lanjutan. Anda tidak harus menjelaskan secara teknis atau langkah demi langkah, namun anda diminta untuk tetap mempertahankan kepadatan, kelengkapan, dan kecukupan informasi yang anda berikan. (11pt)

\section{Hasil dan Diskusi}

Menciptakan masakan yang memiliki kelezatan dengan rasa gurih dan beraroma sedap merupakan kebutuhan masyarakat yang menyebabkan peningkatan kebutuhan akan bahan tambahan masakan untuk membuat masakan tersebut. Bahan tambahan masakan yang dimaksud adalah penyedap rasa. Penyedap rasa instan dalam kemasan yang lebih praktis dengan harga yang tejangkau menjadi pilihan masyarakat yang memudahkan mereka dalam memasak. Hal inilah yang menarik produsen penyedap rasa untuk menawarkan berbagai merek dengan berbagai kualitas kepada konsumen. Saat ini penyedap rasa yang hadir dipasaran dan paling dikenal oleh masyarakat adalah merek Royco, Sasa, Masako, dan Ajinomoto. Berbagai merek penyedap rasa tersebut akan tetap bertahan dan banyak digunakan jika memiliki kualitas yang memenuhi harapan konsumen. Dalam penelitian ini yang menjadi objek penelitian adalah iklan televisi Royco versi ibu yang membuat sup bagi anaknya.

Penggunaan bahasa yang menarik dengan menggunakan pilihan kata yang tepat akan dapat mendorong para pemirsa untuk membeli produk yang ditawarkan, termasuk produk makanan dan minuman yang menjadi kebutuhan pokok bagi masyarakat. Namun ada masyarakat yang tidak memahami secara cermat iklan produk-produk tersebut, karena telah terpengaruh oleh bahasa iklan yang begitu menarik. Alasan inilah yang melatarbelakangi peneliti memilih iklan penyedap rasa di televisi sebagi objek dalam penelitian.

Sebagai perwujudan bahasa, wacana iklan pun memiliki struktur. Struktur ini akan membangun sebuah iklan menjadi sebuah bangun bahasa yang utuh. Penempatan susunan kata dan kalimat memberikan pengaruh yang sangat besar pada pemahaman pemirsa. Selain itu, penyusunan bagian struktur iklan juga dapat mempengaruhi pemirsa sehingga dapat tertarik oleh bahasa iklan dan membeli produk yang diiklankan. Untuk itu, perlu dilakukan kajian untuk melihat struktur tersebut, bagaimana sebuah struktur dapat mempengaruhi pemirsa. Hal ini sejalan dengan pernyataan pendapat seorang ahli sastra Panuti Sudjiman (1990: 33) menyatakan bahwa yang disebut gaya bahasa adalah cara menyampaikan pikiran dan perasaan dengan kata-kata dalam bentuk tulisan maupun lisan.

Dalam analisis penelitian ini, peneliti berusaha untuk memperlihatkan sebuah proposisi dengan memberikan penekanan berupa keuntungan kepada calon konsumen apabila membeli atau menggunakan produk Royco. Proposisi menekankan keuntungan calon konsumen pada iklan produk makanan dan minuman pada televisi terlihat pada data berikut:

\section{"ROYCO, Untuk Hidup Lebih Kaya Rasa"}

Dalam menganalisis kalimat tersebut dapat dinyatakan bahwa, dalam pertaliannya dengan kepiawaian menggunakan kata-kata, gaya bahasa dituntut wajib menjunjung tinggi nilai-nilai kejujuran, kejelasan, dan kehematan (Wahyu Wibowo, 2003: 245). Jika pengiklan dapat memikat sasarannya untuk mendukung bahkan hingga membeli barang produksi yang ditawarkan, maka dapat dikatakan bahwa iklan yang dibuat berhasil. Berbagai versi iklan Royco selalu menampilkan visualisasi keanekaragaman 
masyarakat yang ada di Indonesia berupa keanekaragaman lapisan masyarakat dan budaya melalui masakan yang disajikan diiringi ilustrasi musik.

Penampilan berbagai masakan, dengan menggunakan semiotika, iklan Royco dapat diinterpretasikan bahwa Royco adalah cara jitu guna menarik orang menikmati sebuah masakan. Hal ini sesuai dengan pernyataan Saussure mengelompokkan lambang menjadi dua jenis yaitu signifier dan signified. Signifier menunjuk pada aspek fisik dari lambang misalnya ucapan, gambar, lukisan, sedangkan signified menunjuk pada aspek mental dari lambang, yakni pemikiran bersifat asosiatif tentang lambang (Pawito, 2007:162).

Televisi memiliki kelebihan dan kekuatan dibandingkan media lain. Televisi memungkinkan adanya kombinasi suara, warna, dan gerakan. Melalui alasan itulah yang menyebabkan televisi masih menjadi pilihan utama para pemasang iklan untuk menawarkan produknya melalui media ini. Sebagai media visual utama, televisi menggunakan teknik bercerita dengan gambar (pictorial storytelling), sebuah poin kuat dalam dunia di mana jumlah waktu yang dicurahkan untuk membaca telah menurun (Lee dan Johnson, 2007:267). Bahasa gambar dan suara itulah yang merupakan salah satu bagian dari lambang-lambang bahasa dalam komunikasi dangan pemirsa.

Sebuah iklan yang terdiri dari rangkaian gambar dan jargon, mengandung sesuatu yang dapat menyampaikan pesan sang pengirim simbolnya. Sesuatu tersebut dikenal dengan sebutan tanda (sign) atau semiotik bahasa, yang dapat mengurai makna. Dalam iklan Royco, terdiri dari tiga elemen tanda, yaitu gambar objek atau produk yang diiklankan, gambar benda-benda di sekitar objek, dalam iklan Royco adalah makanan yang memberikan konteks pada merk tersebut dikatakan sebgai sebuah konteks, serta tulisan atau teks adalah hal memberikan keterangan tertulis. Ketiga elemen ini, antara satu dengan lainnya saling mengisi dalam menciptakan ide, gagasan, konsep atau makna sebuah iklan.

Dalam iklan Royco, dihubungkan dengan teori Barthes, setiap tanda selalu memperoleh pemaknaan awal yang dikenal secara umum (denotasi) dan oleh Barthes disebut sistem prime, yaitu Royco sebagai penyedap rasa. Sedangkan segi pengembangannya disebut sistem sekunder. Sistem sekunder yang ke arah ekspresinya disebut metabahasa, artinya E (Royco) dapat berkembang membentuk tanda baru bagi simbol $\mathrm{C}$ (makanan), sehingga ada lebih dari satu $\mathrm{E}$ untuk $\mathrm{C}$ yang berbeda. Hal ini diperkuat dengan pernyataan Benny Hoed (2011): suatu tanda mempunyai bentuk yang banyak dengan makna yang sama. Sedangkan sistem sekunder yang ke arah $\mathrm{C}$ disebut konotasi, artinya $\mathrm{C}$ dapat berkembang membentuk tanda baru, sehingga ada lebih dari satu $C$ untuk E yang sama (45).

Dalam hubungan dengan pernyataan di atas, tulisan yang menggunakan huruf tebal di akhir iklan, merupakan salah satu faktor yang mempengaruhi mudah tidaknya pesan verbal untuk dicermati. Produsen menggunakan huruf kapital dengan tujuan memperjelas apa yang ingin mereka sampaikan sehingga mempengaruhi konsumen atau calon konsumen. Kalimat persuasif atau mempengaruhi adalah jenis kalimat yang sering digunakan oleh produsen pengiklan. Pada kalimat judul di atas ditekankan keuntungan apabila calon konsumen menggunakan penyedap rasa Royco, penekanan keuntungan tersebut terletak pada kata mudah. Penekanan pada judul juga akan menghasilkan efek rasa ingin tahu lebih dalam mengenai kemudahan seperti apa yang diperoleh dengan penyedap rasa, walau pun orang yang memasak tidak bisa memasak.

Dalam Analisis Teks Visual atau Gambar, penlitian ini mengetengahkan gambar pada scene:

Laki-laki: Tantangan rasa ayam Royco. Coba deh! (sambil menunjuk ke mangkuk berisi sup)

Perempuan: (Mengernyitkan dahi)

Laki-laki: Kalau yang pakai Royco ayam?

Perempuan: Kaldu ayamnya mantap banget!

Laki-laki: Yes!

Royco rasa ayamnya lima kali lebih kuat! Sekarang tahukan kaldu mana yang lebih berasa ayamnya?

Dalam iklan Royco versi sop tersebut dapat dianalisis bahwa, apa yang dikatakan oleh lelaki dalam iklan adalah sebagai pemicu. Sedangkan yang dikategorikan sebuah respon adalah prilaku sang perempuan 
pertama kali adalah mengeryitkan dahi. Dalam penelitian ini, peneliti menebalkan kalimat Tantangan rasa ayam Royco, karena di televisi dinyatakan dengan nada penekanan. Hal ini dapat dinyatakan sebsgai badan iklan. Sedangkan kalimat tekanan lain yang mucul pada iklan tersebut adalah, "Sekarang tahukan kaldu mana yang lebih berasa ayamnya!". Teknik penarikan makna semiotika dilakukan melalui penekanan keunggulan produk agar konsumen mengingat produk yang kaldu ayamnya lebih terasa.

Warna pun menjadi pelengkap gambar yang secara visual dapat mempengaruhi representasi orang yang melihatnya. Dalam visualisasi iklan televisi, Royco didominasi dengan warna merah dan kuningnya sup. Tampilan luaran yang digunakan dalam tampilan iklan ini menguraikan bahwa gambar sedikit lebih besar mendominasi layar. Sebuah iklan pasti mengandung suatu pesan dan pesan yang ingin disampaikan terletak dalam segala bagian iklan yang pasti ditujukan untuk mendukung tersampaikannya pesan. Oleh karena itu sebuah iklan mempertimbangkan efektivitas dalam mendukung penyampaian pesan dan tidak hanya menonjolkan sisi kemolekan artistik. Hal ini sangat penting untuk diperhatikan karena pemaknaan khalayak bergantung dari apa yang dilihatnya dan dapat menghasilkan penilaian atau pun interprestasi yang berbeda di setiap tempat.

Dari semua analisis dan penggabungan teori di atas dapat dikatakan bahwa kegunaan ilmu semiotika, adalah membaca tanda dan menarik makna. Makna yang Terkandung dalam Iklan Royco mengatakan bahwa dengan menggunakan Royco, kaum laki-laki yang selalu diinterpreasikan sebagai kaum yang sulit memasak, maka dengan menggunakan Royco kaum laki-laki dapat pula memasak dengan enak. Pemaknaan dari pesan yang disampaikan oleh komunikator tergantung pada persepsi komunikan seperti yang diungkapkan Brodbeck bahwa makna tidak terletak pada kata-kata atau lambang-lambang, namun terletak pada pikiran seseorang, yakni pada persepsinya. Hal ini dinyatakan oleh Rahmat (1994) yang menyatakan bahwa, "Makna terbentuk dari pengalaman individu yang mengacu pada pengalaman sosial budayanya, oleh karena itu makna antara pengirim dan penerima bisa jadi berbeda" (276). Dalam masyarakat banyak sekali isu dan mitos mengenai maskulinitas namun banyak dari isu dan mitos tersebut tidak pasti kebenarannya. Termasuk dalam iklan, kebanyakan penelitian gender mengangkat topik mengenai feminitas dan wanita. Perempuan selalu ditempatkan pada ranah domestik seperti memasak dan bersih-bersih rumah, tapi iklan Royco ini mengedepankan pola yang berbeda. Oleh karena alasan itu, penelitian ini menjadi perlu untuk membantu menjawab isu-isu serta mitos mengenai maskulinitas yang berkembang di masyarakat.

\section{Simpulan}

Berdasarkan hasil analisis dengan pendekatan semiotika terhadap tanda-tanda non verbal dalam iklan Royco versi memasak sup di media televisi, maka sampailah pada bagian kesimpulan dari penelitian ini, yaitu tanda-tanda yang terdapat dalam iklan Royco penyedap rasa versi memasak sop di media televisi merupakan sejumlah tanda-tanda yang mengandung unsur bahasa non verbal seperti ketika sang perempuan mengeryitkan dahinya, di mana konsep tersebut mempresentasikan makna-makna tersendiri. Iklan Royco telah mampu menyampaikan pesan melalui bahasa non verbal yang dapat dimengerti secara umum sehingga mudah untuk dipahami oleh masyarakat.

Hal ini diwakili melalui tanda-tanda non verbal dalam iklan penyedap rasa Royco yang disampaikan melalui pesan kinesik yang terdiri dari pesan fasial yang mewakili beberapa ekspresi wajah seperti ekspresi tidak percaya atau tidak yakin bahkan ekpresi dapat diinterpreasikan sebagi ekpresi bingung. Melalui konsep bahasa non verbal yang ditampilkan oleh iklan penyedap rasa Royco versi "sop" di media televisi, iklan ini juga secara langsung mengajak masyarakat untuk menjadi kreatif, karena menyampaikan pesan dengan makna bahwa tidak hanya perempuan yang dapat memasak. Iklan tersebut juga menyampaikan makna lugas bahwa masakan apa pun akan enak, walau dimasak oleh seorang lakilaki.

\section{Ucapan Terima Kasih}

Terima kasih penulis ucapkan kepada pihak yang telah membantu penulis dalam menyelesaikan penelitian ini sehingga bisa diterbitkan di Jurnal Hortatori. 


\section{Daftar Rujukan}

Aart van Zoest: "Interpretasi dan Semiotika" (terj. Okke K.S. Zaimar dan Ida Sundari Husein)

Berger, A.A. Media And Communication Research Methods. London: Sage, 2000. Print.

Burton, Graeme. Yang Tersembunyi di Balik Media: Pengantar Kajian Media. Yogyakarta: Jalasutra, 2008. Print.

Hoed, Beny H. Semiotika dan Dinamika Sosial Budaya. Jakarta : Komunitas Bambu, 2011. Print.

Jalaludin, Rakhmat. Psikologi Komunikasi. Bandung: Remaja Rosdakarya, 1994. Print.

Keraf, Gorys. Diksi dan Gaya Bahasa. Jakarta: PT Gramedia Pustaka Utama, 2010. Print.

Nuradi. Kamus Istilah Periklanan Indonesia. Jakarta: Penerbit PT Gramedia, 1996. Print.

Priyanto, Doyo. Multivariate Data Analysis, 5th Edition. Prentice-Hall, Inc. New Jersey, 2006. Print.

Sobur, Alex. Psikologi Umum. Bandung: Pustaka Setia, 2003. Print.

Wibowo, Wahyu. Sihir Iklan: Format Komunikasi Mondial dalam Kehidupan Urban-Kosmopolit. Jakarta: Gramedia Pustaka Utama, 2003. Print.

Widyatama. Metodologi Penelitian Kuantitatif. Jakarta : Kencana, 2005. Print. 